\section{Workplace Redesign: Spaces of Work and the Transformation of Industrial Modernity in a Globalizing World}

In recent years, historians have called attention to the significance that space has had in labour history and the history of work. Space is more than a geographic entity in which physical objects, such as houses, farms, factories, and office buildings, are located. In a historical perspective, space also entailed the specific places where people worked and spent much of their time, labour relations were formed, social inequalities and power structures emerged, and labour and social conflicts played out. Although the interwar period is considered to be a turning point in history that opened up a new era of industrial modernity, the aim of this international workshop was to focus more on historical continuity. The workshop attempted to examine the various places of work that coexisted over a one-hundred-year time span.

The meeting, generously funded by the Czech Academy of Sciences (through the "Strategy AV 21 - Top Research in the Public Interest" programme) and hosted by the Masaryk Institute and Archives of the Czech Academy of Sciences on December 1-2 2017 in Prague, attracted experts from different countries and across research fields. The keynote lecture was delivered by Karsten Uhl (Helmut Schmidt University, Hamburg / Darmstadt University of Technology). He explored the forming of the modern factory as a space of work that was influenced by the technology and architecture of its time. In contrast to other places of production, such as manufactories and workshops, the factory as the central symbol of industrial modernity was characterized by the mechanization of labour on a previously unknown scale and the spatial division of family life from work. Uhl underlined the usefulness of Foucault's concept of power for analysing this process. The factory was a place where power was exercised and where specific social relationships emerged. He distinguished three basic periods in the development of factory space, but he stressed their overlapping and non-linear nature.
Beginning in the late nineteenth century, after the era of the early factory had passed, when the exercise of authority in the workplace was based on personal relationships and verbal instructions, new rationalization measures were introduced. New forms of organization, based on written documents and bureaucratization, were established. According to Uhl, the rational factories that became popular in 1920s connected the principles of rationalization and humanisation. On the one hand, newly constructed factory buildings were supposed to facilitate controlling and disciplining workers. On the other hand, these spaces were expected to improve working conditions in order to achieve workers' satisfaction and, hence, better performance. In recent times, the work space in factories has been altered by globalization. The rich discussion that followed the paper centred around sources that could enable the incorporation of workers' perspectives in historical research, the use of particular colours in factories to stimulate employee efficiency, and technological innovations such as artificial lightning.

The first panel focused on spaces of work in nineteenth-century Central Europe. Thomas Schuetz (University of Stuttgart) explored industrialization in the Kingdom of Württemberg using the linen industry as an example. The mechanization and centralization of linen production accelerated in the 1820 s, when flax-spinners and linen weavers, who had traditionally worked at home, were no longer able to compete with cheaper imports from Ireland, and traditional export markets such as France turned to protectionism. Schuetz illustrated that only a limited number of traditional trades managed to adapt to technological changes in production. With linen production shifting to factories, social problems arose. The exploitation of children and women was not merely neglected; it was celebrated in the contemporary paradigm of progress and efficiency. The second speaker, Jakub Raška (Charles University in Prague), shed light on the transformation of the workplace in the printing industry in the second half of the nineteenth century in Prague and Vienna, which influenced the strategies and collective 
agency of workers. With the transition to capitalist-based factory production of books and newspapers, non-qualified machine operators, in large measure women, began to appear in printing offices working next to highly qualified employees. This shift led to workplace conflicts between these two groups that undermined the effectiveness of the labour movement among typographers.

The second day commenced with a panel addressing spaces of work in a globalizing world. Regina Lee Blasczyk (University of Leeds) focused on the broad transcontinental exchange between the United States and Western and Central Europe. In her paper she examined the history of American fashion merchandisers and their working activities in European streetscapes and office spaces from the 1850s until the 1930s. A variety of topics, including business practices, cultural differences, transnational tastes, commercial space, and the daily work routines of resident buyers and stylists, were tackled. The entire presentation was accompanied by a suitable selection of illustrative historic photographs. A different methodological approach was taken by Tryfonas Lemontzoglou (University of Siena). Using cliometrics, he analysed the possible effects of people's access to land and delayed industrialization ("being stuck in agriculture") on literacy rates in Greece in the second half of the nineteenth century. His panel data estimates confirmed a causal linkage between these variables, hence validating the hypothesis that agriculture's dominance over industry had a negative effect on literacy expansion. Finally, Lemontzoglou considered gender issues, concluding that delayed industrialization had a negative influence on female literacy. The second panel was closed by Marcin Jarząbek (Jagiellonian University in Cracow), who refocused attention on Central European workplaces. $\mathrm{He}$ examined the links between space, technology, social order, and work on the railway lines of Austrian Galicia and Russian Poland since they were first laid until 1914. Railway work was spatially organized in a very complex and hierarchal manner. Not only technical issues contributed to the creation of spaces of work on the railway; social status also played a major role. Class differences, in particular, resulted in a clear distinction between the workplaces of manual workers and office workers. Furthermore, engine drivers occupied a special position in the railway hierarchy and its spaces of work, as their job required physical work as well as technological skills and knowledge. Jarząbek stated that social mobility in the railway was therefore strongly connected with spatial mobility. The socialist movement, which began to develop in the late nineteenth century in the railroad industry, tried to overcome these spatial differences by creating a common space for all railway workers.

The third and final panel was devoted to redesigning workplaces in the age of extremes and consisted of three papers. Zdeněk Nebřenský Masaryk Institute and Archives of the Czech Academy of Sciences) explored the structure of factory buildings and shop floors using the example of cotton mills in the Bohemian Lands during the Gründerzeit. He came to the conclusion that the development of homogenous and clearly delimited spaces of work was influenced by new production needs as well as by social issues. On one hand, workplaces were redesigned because they needed to be adapted to cotton, a new commodity that intertwined the imperial periphery with the global exchange of goods. On the other, the arrival of skilled workers meant new amenities needed to be constructed for them on factory premises. Anna G. Piotrowska (Jagiellonian University in Cracow) provided valuable insight into the nature of music-making in concentration camps, choosing the Auschwitz camp network as a case study. She asserted that music-making in camps, which was primarily undertaken by orchestras, was a type of forced labour strictly controlled by camp authorities. Not only were orchestras supposed to provide musical entertainment for SS staff and their families, but their music was also fully integrated into the exploitative and extermination machinery of camps. Special barracks were set aside for musical purposes, such as for rehearsing or storing instruments, whereas concerts took place outside. Hence, death camps were for musicians a specific space of work. The last speaker of the workshop, Mrinmoy Majumder (Flame University in Pune, Maharashtra) 
dealt with the representation of IT workers' common interests in contemporary India. Although trade unions have traditionally been the main organizations protecting and promoting workers' general welfare and have succeeded in improving working and living conditions, a strong union is missing in the Indian IT sector. This traditional form of collective identity is becoming obsolete and redundant in the modern technological service industry. According to Majumder, new forms of collectivization led by individuals empowered by technological tools will likely emerge in India's IT sector instead of typical trade unions. He understands such individuals as a fusion of human and machine with a distinct identity, "proletariat cyborgs."

The closing roundtable discussion summarized the event. All participants appreciated the friendly and productive atmosphere of the workshop and its interdisciplinary character. The presented papers gave insight into different themes, applied various methodological approaches, and covered a period spanning from the end of the eighteenth century to the present. The analytical usefulness of the concept of spaces of work and its variety were thus highlighted. The workshop demonstrated that research on spaces of work does not have to solely focus on physical workplaces such as factories, but it can be more imaginatively extended to cover other places, as the papers about music-making in concentration camps and proletariat cyborgs demonstrated. Many of the presenters indicated that individual workplaces were related to each other. In the discussion, attendees agreed that future research could focus in greater detail on the connections between different, originally separate workplaces (e. g., factory workers who also worked parttime in agriculture and seasonal workforce migrations) and study the factors that facilitated the emergence of ties between them. Further, it was proposed that the architectural and construction aspects of spaces of work could be studied more closely, as throughout the workshop these factors were considered only implicitly, and that the distinctions between workplaces and places of living could also be focused on. The importance of archival research, avoided by some scholars, was also stressed. In summary, the workshop clearly demonstrated the importance of considering the history of workplaces and opened up new questions and perspectives. One can only wish another such meeting will follow soon.

Svatopluk Herc

DOI: $10.14712 / 23363525.2018 .62$ 